\begin{tabular}{c|l|l|l} 
Case Reports $\boldsymbol{h}$ & $\begin{array}{l}\text { Case Rep Dermatol 2010;2:60-64 } \\
\text { D01: } 10.1159 / 000313866\end{array}$ & Published online: April 30, 2010 & $\begin{array}{l}\odot 2010 \text { S. Karger AG, Basel } \\
\text { ISSN 1662-6567 } \\
\text { www.karger.com/cde }\end{array}$ \\
\hline
\end{tabular}

\title{
Skin Detachment and Regrowth in Toxic Epidermal Necrolysis
}

\author{
Laurence Feldmeyer Thomas Harr Antonio Cozzio \\ Lars. E. French Alexander A. Navarini \\ Department of Dermatology, University Hospital Zürich, Zürich, Switzerland
}

\section{Key Words}

Toxic epidermal necrolysis · Lyell · Reepithelialization

\begin{abstract}
Toxic epidermal necrolysis is a rare but clinically well-described dermatological pathology. However, clinical pictures of this disorder in text books do not reflect its dynamic evolution. Usually, the desquamative post-bullous stage is represented, neglecting the initial bullous stage as well as the skin healing. With one clinical case, we provide a day-after-day illustration of the evolution of a patient suffering from toxic epidermal necrolysis. During one month, a skin area of a limb was regularly photodocumented.
\end{abstract}

\section{Case Report}

A 15-year-old female developed fever, stinging eyes and headache, followed one day later by sudden appearance of flaccid blisters on the face with subsequent dissemination to more than $70 \%$ of the whole integument and development of mucosal erosions. Thirty days before, she had been operated on the nose and medicated with cefuroxime (for 8 days), paracetamol (for approx. 10 days) and metamizol (for approx. 10 days), the latter of which was later identified by lymphocyte transformation test as the most likely causative compound. Four days before admission, she had taken acetylsalicylic acid and paracetamol for flu-like symptoms including conjunctival irritation and rhinitis.

Upon physical evaluation, disseminated flaccid blisters filled with serous liquid were present on $70 \%$ of her skin surface. Her eye-, mouth-, pharyngeal- and genital mucosae were also affected by erosive lesions. A skin biopsy confirmed the diagnosis of toxic epidermal necrolysis (TEN) [1]. The calculated SCORTEN was 1. She received intravenous immunoglobulins (IVIGs) [2-4], in total $3 \mathrm{~g} / \mathrm{kg}$ body weight over three consecutive days, hydration and nutritional support as well as careful wound care. Topical therapy included silver-coated dressings on erosions, and after reepithelialization, skin washes with water and wax emulsion were performed, followed by the application of

Laurence Feldmeyer and Alexander Navarin
Department of Dermatology, University Hospital Zürich, Gloriastrasse 31 $\mathrm{CH}-8091$ Zürich (Switzerland)

Tel. +41 44255 1111, Fax +41 44255 4549, E-Mail laurence.feldmeyer@usz.ch alexander.navarini@usz.ch 
hydrocortisone $0.5 \%$ in hydrophilic unguent. From day 1 after onset of IVIG therapy onwards, no new development of blisters was observed. During the clinical course, desquamation of dusky areas of skin leaving an intact epidermis below was observed. We noted frequent spontaneous bleeding upon changes of the silver-coated dressings during reepithelialization period in the second week. The remaining detached skin fragments that overlied the progressively regrowing epidermis as of day 7 were progressively shed between day 7 and day 28. The patient was discharged from the intensive care unit (ICU) at day 28 after admission, with almost complete skin reepithelialization. At the last followup control 6 months later, the patient showed full recovery, except for residual alopecia and dry eyes. Multiple areas of hypopigmentation confined to areas of previous epidermal detachment were also observed.

\section{Current Therapeutic Modalities for TEN}

To date, no specific treatment with a high evidence level of efficacy has been reported for TEN. The standard of care consists of best supportive therapy in an ICU setting, and includes hydroelectrolytic and nutritional support as well as regular wound care and the appropriate detection and treatment of infectious complications. Whereas best supportive care is an accepted standard of care for TEN patients, none of the specific treatment strategies described to date, including IVIG (adequately dosed at $3 \mathrm{~g} / \mathrm{kg}$ body weight; there is an apparent dose dependence, as the reduction in mortality appears to be greatest for doses of 3-4 g/kg [4]), corticosteroids, and infliximab, has shown solid evidence in support of a survival advantage in TEN patients [5]. To date, only one prospective, randomized-controlled clinical trial has been reported in TEN, demonstrating no therapeutic benefit for thalidomide in the treatment of TEN [6]. IVIG is a safe therapeutic modality that has been shown in several case series to potentially provide a benefit in TEN. Controversy as to the exact efficacy does, however, exist [7]. In the recently established guideline for the use of high-dose immunoglobulins in dermatology, early administration of high-dose immunoglobulins $(3 \mathrm{~g} / \mathrm{kg})$ is recommended in the lack of therapeutic alternatives [8]. Indeed, several published studies reporting the use of IVIG for the treatment of TEN have shown this therapy to potentially provide a survival benefit. The studies published to date are unfortunately heterogeneous, and often of limited size, retrospective nature, and noncontrolled. On the other hand, TEN is a rare disease, and randomized prospective controlled studies analyzing the effect of IVIG are very difficult to perform, and do not exist to date. Eight of the 11 studies published to date reporting the use of IVIG in TEN suggest a positive effect of IVIG on mortality if compared to the mortality predicted by SCORTEN where applied, or the $25-35 \%$ average mortality rate for TEN reported in the literature (table 1). It must be kept in mind, however, that as for many other therapies, the total dose (in $\mathrm{g} / \mathrm{kg}$ body weight) of IVIG administered may have an effect on the therapeutic outcome. Indeed, a recent publication by Trent et al., analyzing in detail the studies published to date, showed that a doseresponse relationship likely exists: per 1-g/kg increase in IVIG dose, there was an observed 4.2-fold increase in patient survival. Moreover, no mortality was observed amongst the 30 patients that had received $3 \mathrm{~g} / \mathrm{kg}$ IVIG or more [7]. Taking into account the lack of a proven specific therapy, the severity of TEN, the safety of IVIG, and the data to date concerning the efficacy of IVIG in TEN, we are of the opinion that in the absence of proven superior therapies, IVIG therapy should be considered in patients with TEN. 
Table 1. Overview of the published studies on IVIG use including 10 or more patients

\begin{tabular}{|c|c|c|c|c|c|c|c|c|c|c|c|}
\hline & $\begin{array}{l}\text { Viard } \\
1998[2]\end{array}$ & $\begin{array}{l}\text { Trent } \\
2003[9]\end{array}$ & $\begin{array}{l}\text { Prins } \\
2003[3]\end{array}$ & $\begin{array}{l}\text { Campione } \\
2003[10]\end{array}$ & $\begin{array}{l}\text { Al-Mutaiiri } \\
2004 \text { [11] }\end{array}$ & $\begin{array}{l}\text { Shortt } \\
2004[12]\end{array}$ & $\begin{array}{l}\text { Tan } \\
2005[13]\end{array}$ & $\begin{array}{l}\text { Stella } \\
2007 \text { [14] }\end{array}$ & $\begin{array}{l}\text { Bachot } \\
2003[15]\end{array}$ & $\begin{array}{l}\text { Brown } 2004 \\
{[16]}\end{array}$ & $\begin{array}{l}4 \text { Schneck } \\
2008[17]\end{array}$ \\
\hline Study & PNC & RNC & RNC & PNC & PNC & $\mathrm{RNC}$ & RNC & $\mathrm{RC}$ & PNC & RNC & $\mathrm{RC}$ \\
\hline Patients & 10 & 24 & 48 & 10 & 12 & 16 & 12 & 23 & 34 & 24 & 75 \\
\hline Detach, \% & 39 & 44 & 45 & 49 & 58 & $65^{*}$ & - & - & 19 & 49 & - \\
\hline $\begin{array}{l}\text { Dose IVIG, } \\
\text { g/kg }\end{array}$ & 3 & 4 & 3 & 2 & $2-5$ & 2.8 & 2 & - & 2 & 1.6 & $\begin{array}{l}1.9 \\
(0.7-2.3)\end{array}$ \\
\hline $\begin{array}{l}\text { Predicted } \\
\text { mortality, \% }\end{array}$ & - & $\begin{array}{l}33 \\
(\mathrm{~S})\end{array}$ & - & $\begin{array}{l}35 \\
(\mathrm{~S})\end{array}$ & - & $\begin{array}{l}38 \\
(\mathrm{~A})\end{array}$ & - & $\begin{array}{l}35.8 \\
(S)\end{array}$ & $\begin{array}{l}24 \\
(\mathrm{~S})\end{array}$ & $\begin{array}{l}28.6 \\
(S)\end{array}$ & $\begin{array}{l}25 \\
(S)\end{array}$ \\
\hline $\begin{array}{l}\text { Actual mortality, } \\
\%\end{array}$ & 0 & 4 & 12 & 10 & 0 & 25 & 8 & 26 & 32 & 41.7 & 34 \\
\hline
\end{tabular}

* Initial rash involving $65 \pm 29 \%$ TBSA.

$\mathrm{PNC}=$ Prospective, noncontrolled; $\mathrm{RNC}=$ retrospective, noncontrolled; $\mathrm{RC}=$ retrospective, controlled; $\mathrm{S}=\mathrm{SCORTEN} ; \mathrm{A}=$ APACHE. 


\begin{tabular}{|c|c|c|c|}
\hline $\begin{array}{l}\text { Case Reports in } \\
\text { Denmotology }\end{array}$ & $\begin{array}{l}\text { Case Rep Dermatol 2010;2:60-64 } \\
\text { Dol: } 10.1159 / 000313866 \\
\end{array}$ & Published online: April 30, 2010 & $\begin{array}{l}\text { (C) } 2010 \text { S. Karger AG, Basel } \\
\text { ISSN } 1662-6567 \\
\text { www.karger.com/cde }\end{array}$ \\
\hline
\end{tabular}
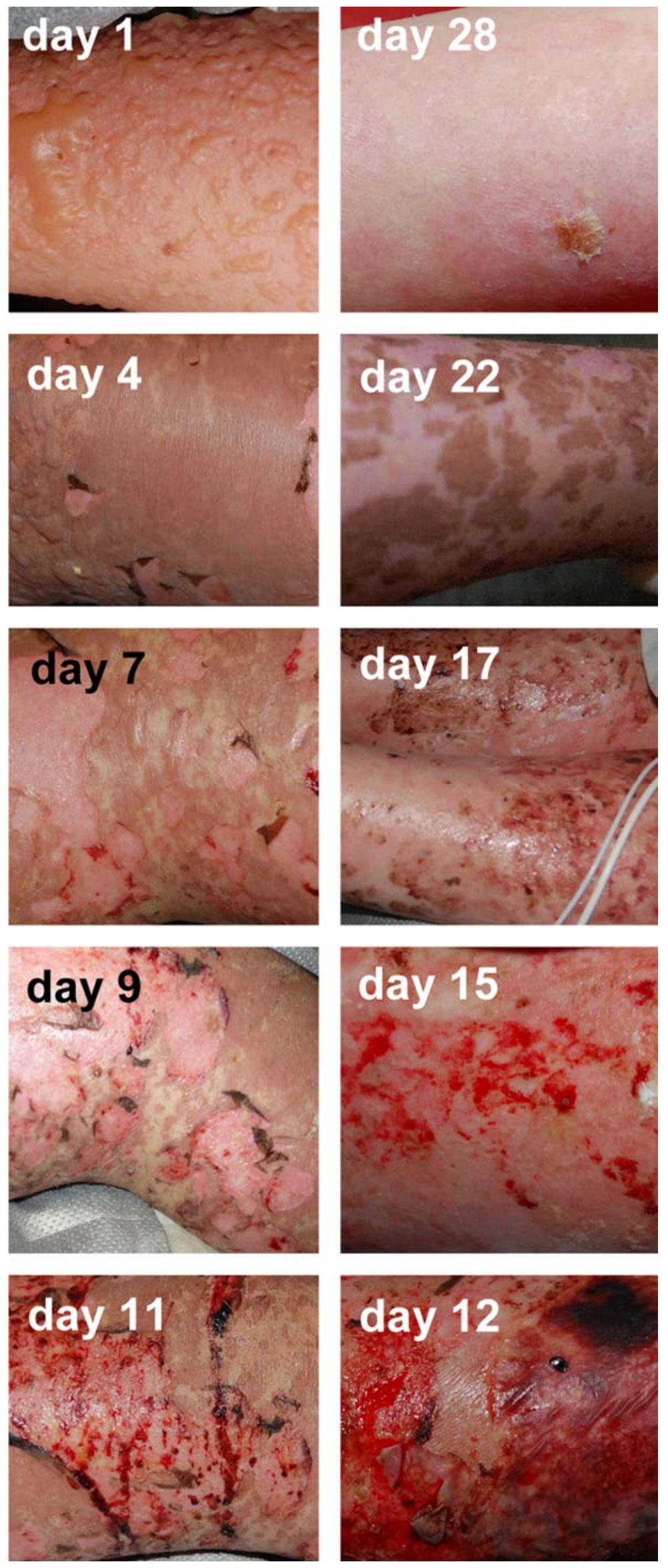


\section{References}

1 Lyell A: Toxic epidermal necrolysis: an eruption resembling scalding of the skin. Br J Dermatol 1956;68:355-361.

-2 Viard I, Wehrli P, Bullani R, Schneider P, Holler N, Salomon D, Hunziker T, Saurat JH, Tschopp J, French LE: Inhibition of toxic epidermal necrolysis by blockade of CD95 with human intravenous immunoglobulin. Science 1998;282:490-493.

- 3 Prins C, Kerdel FA, Padilla RS, Hunziker T, Chimenti S, Viard I, Mauri DN, Flynn K, Trent J, Margolis DJ, Saurat JH, French LE: Treatment of toxic epidermal necrolysis with high-dose intravenous immunoglobulins: multicenter retrospective analysis of 48 consecutive cases. Arch Dermatol 2003;139:26-32.

4 French LE, Trent JT, Kerdel FA: Use of intravenous immunoglobulin in toxic epidermal necrolysis and Stevens-Johnson syndrome: our current understanding. Int Immunopharmacol 2006;6:543-549.

-5 Abood GJ, Nickoloff BJ, Gamelli RL: Treatment strategies in toxic epidermal necrolysis syndrome: where are we at? J Burn Care Res 2008;29:269-276.

-6 Wolkenstein P, Latarjet J, Roujeau JC, Duguet C, Boudeau S, Vaillant L, Maignan M, Schuhmacher MH, Milpied B, Pilorget A, Bocquet H, Brun-Buisson C, Revuz $\mathrm{J}$ : Randomised comparison of thalidomide versus placebo in toxic epidermal necrolysis. Lancet 1998;352:1586-1589.

-7 Trent J, Ma F, Kerdel F, Fien S, French LE, Romanelli P, Kirsner RS: Dose of intravenous immunoglobulin and patient survival in SJS and toxic epidermal necrolysis. Exp Rev Dermatol 2007;2:299-303.

8 Guidelines on the use of high-dose intravenous immunoglobulin in dermatology. European Dermatology Forum, 2009.

-9 Trent JT, Kirsner RS, Romanelli P, Kerdel FA: Analysis of intravenous immunoglobulin for the treatment of toxic epidermal necrolysis using SCORTEN: the University of Miami Experience. Arch Dermatol 2003;139:39-43.

10 Campione E, Marulli GC, Carrozzo AM, Chimenti MS, Costanzo A, Bianchi L: High-dose intravenous immunoglobulin for severe drug reactions: efficacy in toxic epidermal necrolysis. Acta Derm Venereol 2003;83:430-432.

-11 Al-Mutairi N, Arun J, Osama NE, Amr Z, Mazen AS, Ibtesam el-A, Nazeha el-B: Prospective, noncomparative open study from Kuwait of the role of intravenous immunoglobulin in the treatment of toxic epidermal necrolysis. Int J Dermatol 2004;43:847-851.

12 Shortt R, Gomez M, Mittman N, Cartotto R: Intravenous immunoglobulin does not improve outcome in toxic epidermal necrolysis. J Burn Care Rehabil 2004;25:246-255.

13 Tan AW, Thong BY, Yip LW, Chng HH, Ng SK: High-dose intravenous immunoglobulins in the treatment of toxic epidermal necrolysis: an Asian series. J Dermatol 2005;32:1-6.

- 14 Stella M, Clemente A, Bollero D, Risso D, Dalmasso P: Toxic epidermal necrolysis (TEN) and Stevens-Johnson syndrome (SJS): experience with high-dose intravenous immunoglobulins and topical conservative approach. A retrospective analysis. Burns 2007;33:452-459.

15 Bachot N, Revuz J, Roujeau JC: Intravenous immunoglobulin treatment for Stevens-Johnson syndrome and toxic epidermal necrolysis: a prospective noncomparative study showing no benefit on mortality or progression. Arch Dermatol 2003;139:33-36.

16 Brown KM, Silver GM, Halerz M, Walaszek P, Sandroni A, Gamelli RL: Toxic epidermal necrolysis: does immunoglobulin make a difference? J Burn Care Rehabil 2004;25:81-88.

17 Schneck J, Fagot JP, Sekula P, Sassolas B, Roujeau JC, Mockenhaupt M: Effects of treatments on the mortality of Stevens-Johnson syndrome and toxic epidermal necrolysis: a retrospective study on patients included in the prospective EuroSCAR Study. J Am Acad Dermatol 2008;58:33-40. 